called the Frei Korp to beat, bloody and murder Berlin radicals of all shades of red. After this tragedy, the councils "would never again regain such direct influence over government policy" (55). It is commonplace for those on the Left to draw the lesson that this was inevitable in a movement refusing to organise a political party. Of course, this complex and tragic situation cannot be reduced to the need to build a political party, no matter how often some will say it. The party question, as it is often labeled, is beyond the scope of this work.

Many questions remain to be examined: Can a movement based upon the most skilled (and largely male) workers come to represent a diverse and multilayered working class? Can an organisation dominated by men reach out to and win over female workers situated in a different historical experience? How can a movement among relatively secure and better-paid unionists incorporate those in less privileged, casual employment? How can workers toiling on the home front forge a relation with soldiers in the trenches?

This exciting and well-written work brings alive a period that people would do well not to forget. Brief and free of the sort of academic jargon that often frightens non-specialists, this is a work that deserves a wide readership despite any limitations. For those who wish to explore this important and interesting period in more depth, they would be well advised to read the recently published Working-Class Politics in the German Revolution: Richard Müller and the Origins of the Council Movement by Ralf Hoffrogge. While the two works have similar ideological sympathies, Hoffrogge goes into much greater detail and has a wealth of new sources that were not available to Comack. All the same, Wild Socialism: Workers Councils in Revolutionary Berlin is, in many ways, a ground-breaking book for the English reading public. One hopes that it inspires further innovative studies.

William A. Pelz

Institute of Working Class History, Chicago

\title{
David Harris, Civil War and Democracy in West Africa: Conflict Resolution, Elections and Justice in Sierra Leone and Liberia (New York: IB Tauris, 2012). 320 pp. $\$ 45.00$ Paperback.
}

Since Edward Blyden's seminal work, Christianity, Islam and the Negro Race (1887), which characterised Liberia and Sierra Leone as twins whose fortunes will remain inextricably linked, the two contiguous countries have been attractive subjects for comparative analysis. Liberia and Sierra Leone indeed share much in common: they are roughly of equal size, their origin as colonies for repatriated former slaves is unique in West Africa, and they share a more recent history of anarchic civil wars, state collapse, and massive international intervention. But these obvious similarities mask more profound differences - in their historical trajectory, their polit- 
ical culture, and the nature and capacity of their societies.

David Harris draws on their foundational experience to show how their 'creolised' nature helped set the stage for their unhappy recent past. In the process, he glosses over the more important differences between them, leading him to make bewildering general statements like "the Creoles of Sierra Leone and Liberia most probably played a part in creating a model of paternalistic, grossly imbalanced and ultimately detrimental elite-society relations, somewhat aligned with pre-colonial Indigenous political patrimonial practices, and to which the subsequent regimes closely adhered" (209). If this sentence has any meaning, it is only partially true - true to an extent only with respect to Liberia.

When he avoids making easy generalisations, Harris can be both perceptive and penetrating. He is very good, for example, in his analysis of the ambitious role elections are forced to play in conflict resolution in West Africa, and of what he describes - with some acuity - as "externally imposed justice." He describes, in detail and with valuable insight, four elections held in Sierra Leone and Liberia since 1996, though he is wrong to describe Sierra Leone's 1996 elections as "postconflict." I covered those elections as a journalist, and no one at the time - certainly not the Sierra Leonean authorities, or United Nations or the British sponsors - pretended that the war had ended. In fact, those elections were accompanied by a wave of amputations by rogue elements of the National Provisional Ruling Council junta and members of the Revolutionary United Front (RUF), who had vowed to disrupt them; and they were organised as a means of delegitimising the RUF. The "post-conflict" description is part of Harris' error of over-generalisation and a tendency to sacrifice exactitude for theoretical convenience. However, his focused chapters on the electoral processes in the two countries are very insightful.

He is right to argue against the fetishisation of elections as the key tool of conflict resolution, the glorious mechanism bookending violent conflict. Where the causes of conflict are misunderstood or unresolved, elections tend to merely aggravate societal fissures and sometimes lead to wider conflict. The elections in Liberia in 1997, which made Charles Taylor president, resolved nothing: it was, to use Harris' felicitous word, "choiceless" because the electoral field was entirely skewed in Taylor's favour. He was the richest and most powerful man in the country, and the electorate, fearful that he would reignite the war if he lost, overwhelmingly voted for him. Liberia descended into war soon after rival warlords found allies in neighbouring countries willing to rearm them. It has been enjoying a large measure of peace since 2004 largely because of massive United Nations intervention in 2003 - which has been sustained to date. Whether the peace and the democratic experiment - effectively beginning in 2005, with the election of Ellen Johnson Sirleaf, Africa's first elected president - will last beyond the withdrawal of the United Nations peacekeepers is an open question. As Harris notes, Liberia, though it ostensibly became a democratic republic in 1847 , has the weakest polit- 
ical party system - as well as state structures - of almost all countries in West Africa. It can be safely said that Sierra Leone's current democratic experiment begun in 1996 - is likely to last longer and even be sustained. One should also observe in this regard that Harris is wrong to ascribe the elections, from 1996 to date, wholly or even largely to external push or inducement; in fact they are the product of internal campaigns and lots of citizen sacrifice, including the ultimate sacrifice of countless lives.

Harris is seduced by the work of Mark Duffield on "liberal peace." In Global Governance and the New Wars: The Merging of Development and Security (London: Zed Books, 2001), which Harris enthusiastically cites (5), Duffield is justly critical of the tendency by 'liberal peace' to condemn "all violent conduct" so that leaders of any group involved in war "regardless of whether they are guilty of war crimes, which many of them are, or defending themselves from dispossession or exploitation, which some may be," are all criminalised and delegitimised. This is a very important point, which Harris uses in his analysis of the Special Court for Sierra Leone. This court was established by an agreement signed between the UN and the government of Sierra Leone on 16 January, 2002, the month that Sierra Leone's civil war was officially declared ended. Funded mainly by the United States, Britain and other European countries, it convicted former Liberian President Charles Taylor, deemed to have been a key sponsor of the RUF, as well as several members of the RUF for crimes against humanity and war crimes. But it also, bewilderingly, convicted key members of the admirable Civil Defence Force (CDF), which had resisted the RUF and protected local people in remote communities. Clearly, the indictment of persons from all armed groups which participated in the war in Sierra Leone, on the dubious grounds of participating in a "Joint Criminal Enterprise," was an ingenious example of de-legitimising leaders of violent groups in poor countries, and it easily translated into guilt by association.

This left significant bitterness in the parts of Sierra Leone where the CDF was most active, negating whatever positive impact the court could have had. Harris' book makes a valuable contribution highlighting this kind of perversion, and does so in a reasoned and even-handed manner. 